Portland State University

PDXScholar

Business Faculty Publications and

Presentations

The School of Business

Fall 2007

\title{
Open Innovation and Strategy
}

Henry W. Chesbrough

University of California - Berkeley

Melissa M. Appleyard

Portland State University, appleyar@pdx.edu

Follow this and additional works at: https://pdxscholar.library.pdx.edu/busadmin_fac

Part of the Business Administration, Management, and Operations Commons

Let us know how access to this document benefits you.

\section{Citation Details}

Chesbrough, H. W., \& Appleyard, M. M. (2007). Open Innovation and Strategy. California Management Review, 50(1), 57-76.

This Article is brought to you for free and open access. It has been accepted for inclusion in Business Faculty Publications and Presentations by an authorized administrator of PDXScholar. Please contact us if we can make this document more accessible: pdxscholar@pdx.edu. 


\title{
Open Innovation and Strategy
}

\author{
Henry W. Chesbrough \\ Melissa M. Appleyard
}

new breed of innovation-open innovation-is forcing firms to
reassess their leadership positions, which reflect the performance
outcomes of their business strategies. It is timely to juxtapose
some new phenomena in innovation with the traditional academic view of business strategy. More specifically, we wish to examine the increasing adoption of more open approaches to innovation, and see how well this adoption can be explained with theories of business strategy. In our view, open innovation is creating new empirical phenomena that exist uneasily with wellestablished theories of business strategy. Traditional business strategy has guided firms to develop defensible positions against the forces of competition and power in the value chain, implying the importance of constructing barriers to competition, rather than promoting openness. Recently, however, firms and even whole industries, such as the software industry, are experimenting with novel business models based on harnessing collective creativity through open innovation. The apparent success of some of these experiments challenges prevailing views of strategy.

At the same time, recent developments indicate that many of these experimenters now are grappling with issues related to value capture and sustainability of their business models, as well as issues of corporate influence and the potential co-option of open initiatives. In our view, the implications of these issues bring us back to traditional business strategy, which can inform the quest

\footnotetext{
Chesbrough received support from the Center for Open Innovation at the Haas School of Business and the Alfred P. Sloan Foundation. Appleyard received support from the National Science Foundation under Grant No. 0438736. Jon Perr and Patrick Sullivan ably assisted with the interviews of Open Source Software leaders. Any opinions, findings, and conclusions or recommendations expressed in this material are those of the authors and do not necessarily reflect the views of the above funding sources or any other individuals or organizations.
} 
for sustainable business models. If we are to make strategic sense of innovation communities, ecosystems, networks, and their implications for competitive advantage, we need a new approach to strategy—what we call "open strategy."

Open strategy balances the tenets of traditional business strategy with the promise of open innovation. It embraces the benefits of openness as a means of expanding value creation for organizations. It places certain limits on traditional business models when those limits are necessary to foster greater adoption of an innovation approach. Open strategy also introduces new business models based on invention and coordination undertaken within a community of innovators. At the same time, though, open strategy is realistic about the need to sustain open innovation approaches over time. Sustaining a business model requires a means to capture a portion of the value created from innovation. Effective open strategy will balance value capture and value creation, instead of losing sight of value capture during the pursuit of innovation. Open strategy is an important approach for those who wish to lead through innovation.

\section{The Insights and Limits of Traditional Business Strategy}

Business strategy is a wide and diverse field. The origins of the concept hearken back to Alfred Chandler's seminal Strategy and Structure, where he presented the first systematic and comparative account of growth and change in the modern industrial corporation. ${ }^{1}$ He showed how the challenges of diversity implicit in a strategy of growth called for imaginative responses in administration of the enterprise. In his subsequent work, Chandler showed how scale and scope economies provided new growth opportunities for the corporation during the second industrial revolution. ${ }^{2}$

Igor Ansoff built upon ideas from Strategy and Structure and applied them to emerging concepts of corporate strategy. ${ }^{3}$ Strategy came to be seen as a conscious plan to align the firm with opportunities and threats posed by its environment. Kenneth R. Andrews was one of the

Henry Chesbrough is the Executive Director of the Center for Open Innovation at the Haas School of Business, University of California, Berkeley. <chesbrou@haas.berkeley.edu>

Melissa M. Appleyard is an Ames Professor in the Management of Innovation and Technology at the School of Business Administration at Portland State University. <MelissaA@sba.pdx.edu> first theorists to differentiate between a business strategy and a corporate strategy. He held the former to be "the productmarket choices made by division or product line management in a diversified company." ${ }^{4}$ Corporate strategy was a superset of business strategy. "Like business strategy, [corporate strategy] defines products and markets-and determines the company's course into the almost indefinite future. . . A company will have only one corporate strategy but may incorporate into its concept of itself several business strategies." ${ }^{5}$ Thus, a firm's current businesses influenced its choice of likely future businesses as well, an important insight for understanding corporate innovation.

The subsequent analysis of competitive strategy owes a great deal to the seminal work of Michael Porter. In his first book on the topic, ${ }^{6}$ Porter articulated 
a conception of strategy that was rooted in the economics of industrial organization, particularly the model of "structure, conduct, and performance." Essentially, Porter cleverly turned Joe S. Bain's economic welfare analysis of monopoly and oligopoly on its head. Instead of maximizing consumer surplus (the usual economic objective), Porter focused attention upon those actions that would maximize producer surplus. The Porterian model of the Five Forces that shape a firm's competitive strategy-namely, rivalry, buyer power, supplier power, substitutes, and barriers to entry-provided a handy way to identify actions that could enhance a producer's surplus. Items that were previously associated with anti-competitive social welfare outcomes in traditional economic industrial organization theory, such as high barriers to entry, were transformed by Porter's analysis into managerial actions that could enhance a firm's competitive strategy.

In his second volume on strategy, Porter extended the Five Forces concept by linking it to the value chain of a firm, defined as those activities from raw materials through to the final consumer in which a firm's products were developed and marketed. ${ }^{8}$ Positions within the value chain in which there were few competitors or other advantageous characteristics (as defined by the above Five Forces model) could create competitive advantage by profiting from other parts of the value chain in which greater competition could be found.

These seminal contributions made an enormous impact upon both the theory and the practice of strategy. With regard to the latter, consulting firms such as McKinsey, Booz Allen, BCG, and Bain soon developed practices and tools that adapted the Porterian notions of strategy for their clients. Porter even launched his own strategy consulting practice, Monitor Company, to apply his strategy concepts for a variety of clients. Monitor continues to enjoy a thriving practice to this day.

Academics also responded to this new approach to strategy in at least four important ways. ${ }^{9}$ First, scholars such as Anita McGahan extended Porter's concepts through extensive empirical research that broadly supported Porter's concepts. ${ }^{10}$ Second, a former student of Porter's, Richard Rumelt, focused strategy away from industry characteristics toward the characteristics of individual firms. He found that the industry-level differences highlighted in the five forces model were actually less predictive of firm profitability than were differences between firms within a single industry. ${ }^{11}$ Third, a related stream of scholarship called the resource-based view of the firm looked within firms to identify the sources of superior firm profitability, and it isolated ownership of certain key resources as the locus of competitive advantage, rather than the Porterian view of a firm's position in its market and its value chain. ${ }^{12}$ Finally, a fourth stream examined the role of economic complements to the firm's own assets. Controlling key complementary assets afforded firms a comparative advantage, which facilitated entry into new industries. ${ }^{13}$

Each of these directions has proven to be fruitful for understanding business strategy. None, however, in our judgment, can adequately account for some of the new empirical phenomena emerging in many technology-based 
industries. All of the traditional views are based upon ownership and control as the key levers in achieving strategic success. All focus largely within the firm, or within the value chain in which the firm is embedded. None take much notice of the potential value of external resources that are not owned by the firm in question, but may nonetheless create value for the firm. These external resources, such as volunteer contributors, innovation communities and ecosystems, and surrounding networks represent growing sources of value creation.

\section{Emerging Anomalies that Challenge Traditional Business Strategy}

As Donald Stokes observed, science often progresses first from a practical knowledge of how to do something, to a deeper knowledge of why that something works the way it does. ${ }^{14}$ In Thomas Kuhn's notion of paradigm development, empirical anomalies accumulate that (sooner or later) challenge the prevailing conception and trigger the search for an alternative conception that can incorporate the previously inexplicable anomalies. ${ }^{15}$ In strategy, we believe that a number of new and anomalous developments have emerged that require a substantive revision to Porter's conceptions, and to the four branches of research that Porter's work has spawned.

While it is difficult to precisely define the scope of these new developments, we believe that the concept of open source development and similarly inspired ideas such as open innovation, the intellectual commons, peer production, and earlier notions of collective invention represent phenomena that require a rethinking of strategy. ${ }^{16}$

Shifting the focus from ownership to the concept of openness requires a reconsideration of the processes that underlie value creation and value capture. Our notion of openness is defined as the pooling of knowledge for innovative purposes where the contributors have access to the inputs of others and cannot exert exclusive rights over the resultant innovation. In its purest form, the value created through an open process would approach that of a public good. ${ }^{17}$ It would be "non-rival" in that when someone "consumed" it, it would not degrade the experience of a subsequent user. ${ }^{18}$ It also would be "non-excludable" so all comers could gain access.

Typically public goods have been the purview of governments-national defense and education being two widely deployed examples. Recent privatesector phenomena ranging from social networking web sites such as MySpace to open source software such as the Linux operating system have created value along the lines of a public good in that multiple people can use them and no one is excluded from using them.

The value of openness is actually enhanced with every user in two ways. First, users directly contribute ideas and content to improve the quality and variety of the product. MySpace relies on individual contributors, Wikipedia relies on individuals for both data entry and editing, and Linux relies on a global innovation community. Raymond popularized this notion through "Linus's Law," 
which states, "Given enough eyeballs, all bugs are shallow" (i.e., easy to fix). Second, the more users, the more momentum behind the product such that other companies producing complementary goods or services would be attracted to the mass of users. This dynamic, where more users beget more users, has been labeled a "network effect." ${ }^{19}$ In the case of MySpace, Rupert Murdoch's News Corporation found value in the web site's ability to outpace other social networking sites in terms of membership whose demographics-in addition to numbers-are coveted by advertisers. ${ }^{20}$ News Corp.'s $\$ 580$ million acquisition of MySpace's parent company in 2005 put a dollar figure on the value created. The value of Linux's contributions to global computing is reflected in the value of its ecosystem (including software and servers), which was estimated to reach roughly $\$ 18$ billion in $2006 .^{21}$

These types of open innovation products challenge some of the basic tenets of traditional business strategy. The first tenet called into question is the need to have ownership over the resources that are creating the value. MySpace, YouTube, Wikipedia, and Linux have relied primarily on external, volunteer contributors. The second tenet is the ability to exclude others from copying the product. While ownership of the posted content in the case of MySpace and YouTube certainly is central to their valuations, the users can access the sites and view the content without a charge. Like Linux, Wikipedia relies on its user base to continually refine the product. To guarantee transparency of the open innovation process, Wikipedia has a formalized paper trail whereby the Wikipedia Foundation maintains a log of all of the data entries and the editors of those entries, so that the community can see the origins of entries and the history of subsequent edits to those entries. ${ }^{22}$ In the case of Linux, its rules governing the software ensure that the source code will be open for all to see and that the open source code ensures that the kernel will be open for all to see, and that any accepted revisions and improvements will also be open.

When considering the tenets of Porter's Five Forces as the basis of an advantageous competitive position, additional empirical anomalies have emerged. Google and YouTube came into existence without the benefit of significant entry barriers. When considering switching costs on the Web, people can shift to alternative technologies with the click of a mouse. In Porter's view, rivalry reduces industry profits, yet the search industry has many competing technologies with highly profitable companies such as Google and Yahoo! Indeed, Microsoft's masterful cultivation of the Five Forces of Porter has done little to slow Google's meteoric rise in market capitalization. YouTube's acquisition by Google in 2006 for $\$ 1.65$ billion in stock similarly attests to the fact that entry, even when entry barriers are low, can lead to a formidable value creation.

\section{Towards a More Open Approach to Strategy}

Individually, these examples might seem to be mere curiosities. Taken together, though, they imply that something new is going on; something that cannot adequately be explained through the classic conceptions of business 
strategy. Items that were of central importance in earlier strategy treatments, such as ownership, entry barriers, switching costs, and intra-industry rivalry are of secondary importance in the genesis of the above phenomena. Forces that were either peripheral to the earlier treatment or ignored entirely, such as attracting the participation of individual volunteers, the role of community participation, the construction of innovation networks, and the notion of innovation ecosystems all lay beyond the explanatory power of current notions of strategy.

To further understand value creation and capture in this context, we consider two primary manifestations of openness-open invention and open coordination.

\section{Knowledge Creation through Open Invention}

As alluded to above, the power of openness in terms of value creation resets largely with the inherent characteristic of knowledge-it can be reused and can lead to increasing returns. ${ }^{23}$ Furthermore, both the breadth and depth of the pooled knowledge can outstrip the knowledge endowment of an individual contributor. One strategic issue for a firm or organization is how to cover the costs of knowledge creation to get this virtual cycle going.

What has proven astounding is that, without direct monetary compensation, a vast number of resources have been committed to open invention, which applies our notion of openness (defined above) to the creation of a new product or service. The poster child for open invention is Linux. Countless person-hours around the globe have been committed to the development, testing, and adoption of this operating system. Skilled programmers rallied around the initial code supplied by Linus Torvalds, and these lead users drove the Linux movement. ${ }^{24}$ The enthusiasts that triggered the movement gave rise to an innovation community. The resultant OS has been lauded for its superiority over competing "closed" operating systems along the lines of security, configurability, and reliability. ${ }^{25}$ The created value is reflected in the extensive adoption of Linux, where the Linux OS constituted over 13 percent of worldwide server revenue by $2007^{26}$ and has surpassed the Mac OS as the second most widely deployed personal computer OS. ${ }^{27}$

\section{Ecosystem Creation through Open Coordination}

In addition to open invention, open coordination has led to consensus building around issues such as technology standards that have permitted whole business ecosystems to flourish. A business ecosystem represents the interplay between multiple industries, ${ }^{28}$ so a decision to open up a segment of one industry can have widespread reverberations. As Moore observers, an example from the 1980s is IBM's decision to open up its personal computer (PC) architecture. ${ }^{29}$ This led to the rise of the "clones" as companies such as Compaq emulated the IBM specifications. IBM's architecture couple with Microsoft's operating system and Intel's microprocessors became the de facto technology standards in the PC industry. 
FIGURE I. Open and Closed Innovation

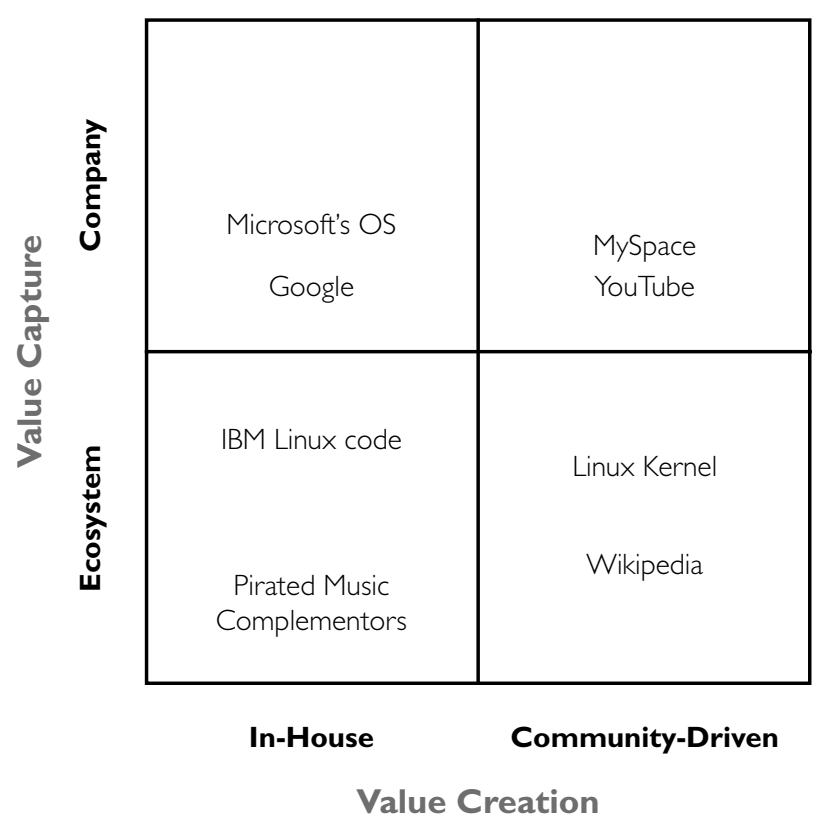

The widespread adoption of this triad contributed to the health of the surrounding ecosystem, which includes application software vendors, video content developers, Internet services providers, and so on. Because PC users want to interact through file sharing and through using numerous software programs, they gravitate to the architecture with the largest footprint. This means that a healthy ecosystem can further perpetuate the adoption of the open architecture through network effects, ${ }^{30}$ where the value of the user network is heightened with each additional adopter. Advancing the ecosystem similarly requires community investment in creating new knowledge and exploring alternative architectures to connect the disparate elements of that knowledge together in cohesive ways. ${ }^{31}$

The lingering questions for the business strategist are: Who actually is capturing the value created by open invention and coordination? How are they doing it? The matrix in Figure 1 arrays open initiatives and closed initiatives to illustrate the range of outcomes on both dimensions. On the value creation dimension, initiatives can differ in whether value is created in-house or via a community. On the value capture dimension, an initiative might see its value realized by a company, or by the larger community.

A particular company involved in the innovation process might be able to capture the bulk of the value by closing off the innovation and protecting it with intellectual property (IP) rights-for example, Microsoft's source code for its operating system. Similarly in Google's case, while it captures value from 
advertisers rather that its user-base, it has been able to distinguish itself through proprietary search algorithms and auction-bidding systems for advertisers. While significant value has accrued to these individual companies, they also have created value that has been captured by their surrounding ecosystems, hence they are placed in the lower portion of the top left quadrant. For example, throu gh its association with Microsoft's operating system, Intel has garnered the leading position in the semiconductor industry, and the personal computer ecosystem has revolved around the "Wintel" de facto standard. By placing paid ads to the right of search results on Google, eBay has bolstered its leadership position in online auctions in the e-commerce ecosystem.

In contrast, in the lower right quadrant, community-driven initiatives can result in products more akin to a public good, leading to value capture that is diffused across an ecosystem. The Linux kernel and Wikipedia are examples. They represent instances of collective invention and coordination. MySpace and YouTube reside in the upper right quadrant, because they rely on communitycontributed content, but the IP controls permit the owners of the content, News Corp. and Google, respectively, to "monetize" the content through vehicles such as targeted advertising. ${ }^{32}$ The final quadrant, the lower left, reflects innovation initiatives that are fueled by resources within a particular company, but the broader ecosystem captures most of the value, relative to the originator. Two examples populate this quadrant-pirated music and IBM's Linux code. While the proceeds of legitimate music sales accrue to the record labels and their artists and bolster the sales of complementary products in their ecosystem, pirated music only benefits the complementors such as Apple and others, which sell music players. The contribution of code to the Linux kernel by IBM comes from software developers on the payroll of IBM. While IBM can capture value by supplying other goods and services in the value chain, the members of the broader computing ecosystem are free to use the resultant operating system.

A critical element to coordinating the value created through open invention is some underlying architecture that connects the different pieces of knowledge together. This systems-level knowledge may reside in a single company (e.g., IBM in PCs), a collection of firms (e.g., Intel and Microsoft in PCs), a consortium (e.g., SEMATECH in semiconductor equipment), or a nonprofit body (e.g., the Linux Foundation). Without some sense of how the system must operate, open knowledge will not accumulate into useful solutions to real problems.

\section{Open Business Models in Open Source Software}

By pooling intellect in a system architecture, open invention and open coordination can produce superior products and services relative to those produced by a smaller number of minds huddled together in a single company. The strategic issue becomes how to capture and then sustain the created value without alienating the individuals, communities, or ecosystem members responsible for the continued development of the good, service, or standard.

While open initiatives often arise from highly motivated individuals or creative communities, a number of approaches have emerged from firms 
engaged in open innovation to foster value capture and sustainability. Perr, Sullivan, and Appleyard have identified seven "open business models" in the context of open source software (OSS): support, subscription, professional services, proprietary extensions, dual license, device, and community source. ${ }^{33}$ In that support, subscription, and professional services are business models found in the proprietary side of the software industry as well, they have not raised many eyebrows. Examples of companies pursuing these models in the open source setting are JBoss (support for application servers), ${ }^{34}$ Red Hat (subscriptions for enterprise-versions of Linux), and IBM (a range of professional services for installation and optimization).

Business models novel to the open source software arena include the development of proprietary extensions or add-ons. Companies pursuing this type of model generally have claim to the primary intellectual property covering the application, but they choose an open source software license to help proliferate the product and then offer "enterprise" versions to paying customers, and these versions are generally more stable or have increased functionality. In customer relationship management applications, SugarCRM follows a business model of this sort. The dual license approach is similar to the proprietary extensions model, but it focuses on the type of license under which the software is being distributed. Companies such as MYSQL, known for its database products, follows this model by licensing their products under different licenses depending on the intent of the end-user.

The final two business models also are specific to the OSS world. The device model leads companies such as Mazu Networks to offer devices that interact with open source software. In the case of Mazu Networks, the devices are related to network security. The community source model entails having users with almost identical needs pool their resources to address the particular need. The Sakai project pursues collaboration tools for learning environments, and numerous universities are actively involved.

These models can be further grouped in to four categories: deployment, hybridization, complements, and self-service (as reflected in Table 1). In the first category, deployment (which spans support, subscription, and professional services), innovation activities heighten the user experience, and users are willing to pay for it even if the initial technology is free.

The second is hybridization, in which proprietary innovation investments are made that rely on intellectual property ownership for add-ons (proprietary extensions). A separate instance of this is "versioning," 35 where multiple versions of a technology such as a public free version and a private commercial version are offered. In open source software, this is called a dual license provision.

The third category is complements, where a vendor may sell a PDA, cell phone, or other device at a profit that runs an open source application software suite or operating system. In this category, the value of the complement is actually enhanced by the free nature of the open technology. As the price of the open technology declines, the price to the consumer of the bundled solution 
TABLE I. Open Source Software Business Models

\begin{tabular}{|c|c|c|c|}
\hline Category & Model & Description & Example \\
\hline \multirow[t]{3}{*}{ Deployment } & Support & $\begin{array}{l}\text { Revenue derived from sale of customer } \\
\text { support contracts. }\end{array}$ & Joss \\
\hline & Subscription & $\begin{array}{l}\text { Revenue derived from annual service } \\
\text { agreements bundling open source } \\
\text { software, customer support and } \\
\text { certified software updates delivered } \\
\text { via Internet. }\end{array}$ & $\begin{array}{l}\text { Red Hat Enterprise } \\
\text { Linux }\end{array}$ \\
\hline & $\begin{array}{l}\text { Professional Services/ } \\
\text { Consulting }\end{array}$ & $\begin{array}{l}\text { Revenue derived from professional } \\
\text { services, training, consulting, or } \\
\text { customization of open source software. }\end{array}$ & $\mathrm{IBM}$ \\
\hline \multirow[t]{2}{*}{ Hybridization } & $\begin{array}{l}\text { Proprietary } \\
\text { Extensions }\end{array}$ & $\begin{array}{l}\text { Firms broadly proliferate open source } \\
\text { application and monetize through sale } \\
\text { of proprietary versions or product line } \\
\text { extensions. Variants include mixed open } \\
\text { source/proprietary technologies or } \\
\text { services with free trial or "community" } \\
\text { versions. }\end{array}$ & SugarCRM \\
\hline & Dual License & $\begin{array}{l}\text { Vendor licenses software under } \\
\text { different licenses (free "Public" } \\
\text { or "Community" license vs. paid } \\
\text { "Commercial" license) based on } \\
\text { customer intent to redistribute. }\end{array}$ & MySQL \\
\hline Complements & Device & $\begin{array}{l}\text { Vendor sells and supports hardware } \\
\text { device or appliance incorporating } \\
\text { open source software. }\end{array}$ & Mazu Networks \\
\hline Self-Service & Community Source & $\begin{array}{l}\text { Consortia of end user organizations or } \\
\text { institutions jointly develops application } \\
\text { to be used by all. }\end{array}$ & The Sakai project \\
\hline
\end{tabular}

Source: Adapted from Jon Perr, Patrick Sullivan, and Melissa M. Appleyard, "Open for Business: Emerging Business Models for Open Source Software Companies," working paper, Lab2Market, Portland State University, 2006.

(open technology plus the complementary device) also falls, thus increasing demand for the device without the manufacturer lowering the price of the device.

The fourth category is a self-service model, where a user community creates a software application for its own needs. ${ }^{36}$ The first three categories clearly incorporate an element of value capture. Only the last category omits an explicit value capture mechanism. This raises the question of whether this last model is sustainable over time.

These four types of open business models are not mutually exclusive, they may evolve over time, and companies frequently pursue more than one simultaneously. Even firms that have followed the prescriptions of traditional 
business strategy by placing IP ownership in the center of their business models may wish to consider these approaches to value capture. While a growing number of open invention examples like Linux provide legitimate paths to knowledge creation through volunteerism, an illegal path also exists-piracy. Greatly facilitated by technological change, pirated music and video downloads and knock-off goods (ranging from handbags to pharmaceuticals) have entered the marketplace against the wishes of the original inventors. The enforcement of IP rights can curb the pirates' ability to profit form this "forced" openness, but such legal actions are costly. Because of the difficulty policing and punishing such activity, inventors who thought their business model would rely on patents or copyrights also may wish to consider these alternative approaches to value capture beyond IP enforcement.

\section{Open Innovation beyond IT}

The emerging anomalies are by no means confined to the information technology sector. There are a number of new developments in the life sciences, such as the Public Library of Science, where open initiatives are powerfully shaping the face of drug development. This is particularly true for developing new drugs in areas that have not attracted significant commercial interest, such as anti-malarial drugs as well as vaccines. Other recent scholarship has documented the role of innovation communities in the emergence of the snowboard, windsurfing, and skateboarding industries. ${ }^{37}$ While we do not wish to suggest that this open approach will migrate to every industry, its emergence is more broad than might be initially realized. As communication costs continue to plummet, facilitating open invention and coordination, it is likely that further open initiatives will take root in more industries around the world.

\section{Issues Confronting the Sustainability of Open Source and Related Initiatives}

There are many issues and challenges that the practitioners of increased openness face as they seek to sustain their businesses. While the many successes of open source and related initiatives are rightly acknowledged by their enthusiasts, there are signs that these new approaches to innovation face significant challenges as well. In particular, it is not yet obvious whether and how these initiatives will be able to sustain the ideals and institutions that were used to construct them at the outset. Unless these initiatives demonstrate the ability to prosper and endure, they could become flashes in the pan that, while interesting, ultimately make little impact on technology and society.

Let us start here by examining the single best known and perhaps most successful instance of an open approach: Linux. This open source operating system software was first developed in 1991 by Linus Torvalds. Starting at a code base of roughly 10,000 lines, by 2003, nearly 6 million lines made up the heart of the Linux OS-the Linux kernel. Its support by an extended community is impressive, with more than 130,000 people actively contributing to its 
development. ${ }^{38}$ Linux's market share in network server market is substantial, with a share of $33 \%$ in 2007, along with a more modest 3 percent of users in the personal computer segment. ${ }^{39}$

Linux development has been institutionalized through the creation of the Open Source Development Labs (OSDL), located in Portland, Oregon. OSDL was funded largely by the contributions of corporations such as IBM, Intel, HP, and Oracle, who have embraced Linux as part of their own business models. Recently, OSDL merged with the Free Standards Group to form the Linux Foundation, and in our view this merger reflects the success of open source on one hand and its shortcomings on the other.

In terms of success, the merger has been viewed as a testament to the maturity of Linux where consolidation of Linux efforts to assist with issues such as version compatibility was an appropriate next step..$^{40}$ Linux has become so successful and so widely adopted that questions of version compatibility have become important. On the side of shortcomings, it was apparent that if OSDL had tried to migrate to a self-funding model by "monetizing" open source opportunities that complemented Linux, its sponsoring corporations might have resisted. This suggests that openness may have a limit if adjacent areas of business are viewed as areas of competition rather than cooperation by corporate sponsors. On the board of the Linux Foundation are again IBM, Intel, HP, and Oracle. Board seats reportedly involve a contribution to the Linux Foundation of $\$ 500,000$, an amount obviously well beyond an individual's wherewithal that effectively skews the governance of the Linux Foundation towards corporations. $^{41}$

While it is premature to judge the final impact of this restructuring, one can already observe a significant retreat from the initial ideals of the Linux movement, as individuals play a diminished role in the ongoing governance of Linux and corporations play an increasingly important and visible role. One also can infer that a significant risk now exists, where the future development of Linux may be co-opted by the agendas of its corporate governors, rather than the ideals of a community-based meritocracy (in which the best code always wins). One can further infer that the risk is not simply that the Linux agenda may be hijacked; all that is required is that a substantial portion of the community begins to believe that the agenda is being hijacked. Once they perceive that to be true, these contributors will take their ideas and contributions elsewhere. This could trigger a collapse within the community, and indeed at that point the corporations would be forced to either support it themselves (thus fulfilling the prophecy) or to abandon it and search for greener pastures.

Thus, the first important issue that open-oriented organizations must face is how to attract the participation of a broad community of contributors, and then how to sustain their participation over time. These contributors do not work for the organization and have many other alternative ways to spend their time and talent. If and when a substantial portion of the contributor community perceives that their initiative no longer is driven by the goals that attracted them to the 
community in the first place, there is a real possibility of collapse of that community. ${ }^{42}$

Linux, we hasten to note, is arguably the most successful example of open source software development. More pedestrian initiatives face considerably more daunting prospects for sustainability. On SourceForge.net, for example, one can find tens of thousands of projects that intend to use an open source method for software development. A casual visit to the site, however, reveals that a few dozen at most have received any significant support from individual software contributors. This reveals a second important issue: the supply of such contributors is not infinite, and the vast majority of projects suffer from a lack of contributors. So open-oriented projects must compete for contributors-and most do not succeed in this competition.

One way to compete for contributors is to look for large groups of contributors who can engage with the community. Many such groups can be found inside corporations. In many open source projects, much of the development is done by programmers on the payroll of large corporations. ${ }^{43}$ The community contributes to a point and may help with quality control, but company employees contribute the vast majority of the code. This additional participation benefits the open initiative, but raises risks.

A third important issue is how the open invention or coordination project is led, and how its agenda evolves. Every community has insiders and outsiders, whether literal or virtual. The insiders typically lead the community and control the direction of its agenda. Most open innovation communities conceive of themselves operating as a meritocracy, where contributors-who often are users of the output as well ${ }^{44}$ - provide their inputs for the betterment of the project, as measured by the achievement of the goals and ideals of the project that caused the contributors to join the project initially. If the community becomes dominated by individual contributors who are working for corporations, the perception of a meritocracy rapidly erodes. A sustainable approach to utilizing an innovation community of contributors must identify ways to recruit contributors, keep them engaged, and avoid the perception (let alone the reality) of being co-opted by agendas at odds with the values of that community. In some of the other open examples proffered by enthusiasts such as von Hippel ${ }^{45}$ and $\mathrm{Shah}^{46}$ (such as skateboarding, snowboarding, windsurfing, and the electric guitar industry), innovation started out in open communities but later migrated to become for-profit industries as the number of users grew and a commercial market developed.

A final strategic concern comes from looking at open initiatives from the perspective of the corporation. How can a company engage in an open source community (so as to obtain the benefits of the depth, variety, and quality of technology found in open initiatives) and still profit from that technology, which, by the terms of the intellectual property that governs the community, cannot be owned by the company? If companies cannot find ways to profit from their innovation activities in open initiatives - through deployment, hybridization, complements, or self-service, they cannot sustain their participation in those initiatives over time. 
While many open source software companies have actively sought community input, over time, the majority of code comes to be written by programmers on staff. This migration from the pure form of open invention to a more hybridized form of open and owned invention is one way that open-oriented firms can control their own destiny. The challenge is managing the mix to avoid alienation of the community, which could precipitate a product war where an open alternative is created to displace the portion that is protected by IP. Well aware of the threat of backlash, open source software companies have been known to focus on developing proprietary code protected by IP only for add-ons that lay outside the areas of interest of the coders in their open innovation community. ${ }^{47}$ Clear communication with the open innovation community, confirming that a particular add-on would not be a priority of the community, becomes a managerial imperative.

\section{How Traditional Business Strategy Can Inform Open Initiatives}

Ironically, we believe that the best chance for open initiatives to sustain themselves will come from returning to the perspectives of traditional business strategy. If we must compete for contributors to build effective innovation communities, how can we position ourselves to win in that competition? How do we differentiate ourselves to these contributors? If companies must find ways to profit from their participation in open source initiatives, how can they differentiate their products and services in the eyes of customers? Are there places in the value chain or in the surrounding ecosystem where we should be more closed, even as we strive to be open in other places? Are there new business models that combine the prospect of the value creation that derives from openness, with the mechanisms for some degree of value capture necessary for sustainability?

For starters, traditional business strategy has spotlighted settings in which cooperation would likely break down. Fierce rivalry may lead to opportunistic behavior during either open invention or coordination. Alliance partners have been found to engage in "learning races" where the relationship dissolves after one partner aggressively extracts knowledge from the other partner. ${ }^{48}$ As dictated by the resource-based view of the firm, employees who are intellectual powerhouses may be jealously guarded, such that their employers would only send "second-stringers" to open invention or coordination initiatives. ${ }^{49}$ This could lead to an inferior outcome from the open process. These issues are particularly salient in "one-shot" open initiatives where reputation effects cannot be relied on to deter bad behavior. Mindful of these types of scenarios, leaders of open initiatives can work to establish norms and rules governing the contributors to avoid sub-optimal outcomes for the community.

Traditional strategy also provides two guideposts for value capture. The first points to IP ownership and the second points to creative management of the value chain. As noted above, open source software companies that follow a hybridized business model participate in open invention but also offer either 
proprietary extensions or a commercial version of their software. At times, this mix between open and closed requires managerial finesse vis-à-vis the community, but in general it has been accepted as a path to profitability. In the case of social networking sites such as MySpace, access may be open, but News Corp.'s ownership of the posted content facilitates additional business opportunities such as a data-mining capability to help with targeted advertising. With additional opt-in features that users are invited to provide for some personal benefit, social networking sites can deliver highly qualified targets for a variety of business purposes.

Even the Porterian notion of the value chain can unleash openness. For example, Intel and IBM have been avid supporters of Linux. Opening up the software link in the electronics value chain has brought down the cost of computing leading to market growth, which means more chip sales for Intel and more hardware sales and service engagements for IBM..$^{50}$ Mirroring some OSS companies' sale of devices (as noted above), Intel and IBM sell goods and services that complement the open link in their value chain. Open coordination similarly has "opened up the stack" whereby coordination around interface standards has dismantled monolithic "vertical" value chains like in the telecommunications industry in favor of a bunch of "horizontal" firms specializing in one link of the chain.

Finally, open initiatives may allow for the creation of whole new complementary links in a value chain. As an example, Tim O'Reilly through O'Reilly Media has established a publishing empire in concert with the rise of open source software. The international conferences sponsored by O'Reilly Media are well attended by the OSS faithful, and because he has been so successful in convening intellect, the attendees do not appear to begrudge him his success.

Another strategic perspective that needs to be confronted is whether and when the costs of openness exceed the benefits of openness. Can there be such a thing as too much openness? While more openness is always better in the enthusiasts' accounts of open initiatives, other academic research has found costs, as well as benefits, to developing and maintaining communities and networks. Hansen's analysis of internal networks inside a large firm found that it was costly to maintain ties within the network past a certain size. ${ }^{51}$ Laursen and Salter's analysis of data from the British government's Survey of Manufacturers found that respondents' innovation outcomes were positively associated with greater openness (as measured by utilizing a greater number of innovation sources). ${ }^{52}$ This association, however, had its limits. Past a certain number of innovation sources, respondents' outcomes became negatively associated with further innovation sources. So more openness and a larger innovation community are valuable, but perhaps only up to a point.

\section{Open Strategy: Illustrative Examples}

As we ponder the implications of business strategy for open initiatives, a number of emerging business models attempt to balance the benefits of openness with the need for some value capture for greater sustainability. In addition 
to the OSS business models noted above, another recent example of an open strategy was the decision of pharmaceutical manufacturer Merck to create the Merck Gene Index. This was an initiative in which Merck funded extensive extramural research activity in universities around the world to produce genetic markers that could serve as targets for later drug development. Once these markers were found, they were compiled and published in Merck's Gene Index. This created a public domain of knowledge that functioned as an intellectual commons for Merck.

While Merck did not have any exclusivity in accessing the markers in its published Index, that was not its objective. Instead, Merck sought to pre-empt the prospect of small biotech firms patenting these markers, thus inhibiting Merck's ability to develop compounds that might turn into new drugs. ${ }^{53}$ Merck expected to capture value in its downstream drug development activities and wanted to create a more open source of inputs in the upstream process of identifying potential areas to investigate. So it was balancing value creation upstream in its value chain, while capturing value downstream. This is an instance of what we mean by open strategy.

As noted above, another example of an open strategy that balances value creation and value capture comes from IBM's own involvement with Linux. Readers of a certain age will recall that IBM practiced a distinctly proprietary business model in software for decades, a model that launched products that included Fortran, COBOL, DB2, and AIX, to name but a few of the most salient products. By the late 1990s, however, IBM's software business began to embrace Linux and to construct its own business model around the Linux code. This was a model that was distinctly different from those earlier proprietary software models. As Joel Cawley of IBM explained:

"I have long observed that it takes $\$ 500 \mathrm{M}$ to create and sustain a commercially viable OS [operating system]. Today we spend about \$100M on Linux development each year. About $\$ 50 \mathrm{M}$ of that is spent on basic improvements to Linux, how to make it more reliable. The other $\$ 50 \mathrm{M}$ is spent on things that IBM needs, like special drivers for particular hardware or software to connect with it. We asked the Open Source Development Lab to estimate how much other commercial development spending was being done on Linux. This didn't count any university or individual work, just other companies like us. They told us the number was $\$ 800-900 \mathrm{M}$ a year, and that the mix of basic vs. specific needs was close to $50 / 50$. So that $\$ 500$ million investment [required for an operating system] is also there now for Linux as well (counting only the basic portion, not the specific portion). And we only pay $\$ 100 \mathrm{M}$ toward that. So you can see even from a very narrow accounting view that this is a good business investment for us." ${ }^{14}$

And the specific portion of IBM's funding of Linux allows its internal programmers to optimize the code base to run very effectively with IBM's other hardware and software products. IBM makes good money on these complementary hardware and software items (a variation on the device category noted above), so participating in a community at one level of value creation leads to greater value capture higher up the stack of value added activities for IBM. 
Executing this new, open strategy required some major internal changes within IBM, and also required IBM to change the opinions of many outsiders who were skeptical about working with IBM. It wasn't easy. Outside Linux participants, for example, were afraid that IBM would destroy the values of the Linux community, either intentionally or unintentionally. As Jerry Stallings, IBM's VP of IP and Strategy described it, "IBM's reputation was a big sometimes arrogant company that takes over whatever it gets involved in. We had to learn how to collaborate."

\section{Conclusion: Open Strategy Balances Value Creation with Value Capture}

Open strategy balances the powerful value creation forces that can be found in creative individuals, innovation communities, and collaborative initiatives with the need to capture value in order to sustain continued participation and support of those initiatives. Traditional concepts of business strategy either underestimate the value of open invention and open coordination, or they ignore them outright. As the concept of openness spreads from software to science and other industries, we will need to update our concepts of strategy. Open strategy is an attempt to supply this update.

In open-dominated industry segments, such as open source software, new business models have been established. The models often blend elements of open and closed innovation. The Oss business models fall under four primary categories: deployment, hybridization, complements, and self-service. These models may apply to other industries as openness spreads.

At the same time, open initiatives must confront real and serious challenges to their ability to sustain themselves over time. While building broad communities of motivated individuals can unleash creative contributions, these are difficult to sustain over time. Attracting and retaining contributors, preventing co-option of the innovation agenda, and covering the fixed costs of innovation all represent non-trivial managerial headaches. As noted, even the most celebrated example of openness, the Linux kernel, now confronts significant changes that may threaten its ability to remain open.

These issues of sustainability bring us back to traditional business strategy, which can make important contributions to mitigating them. If we are to make strategic sense of innovation communities, ecosystems, networks, and their implications for competitive advantage, we propose that a new approach to strategy-open strategy-is needed. Open strategy balances the tenets of traditional business strategy with the promise of open innovation. Certain companies appear to be constructing open strategies. These examples are worth studying, and may point the way forward for both openness and for strategy in leading through innovation. 


\section{Notes}

1. Alfred Chandler, Strategy and Structure (Cambridge, MA: MIT Press, 1962).

2. Alfred Chandler, "The Enduring Logic of Industrial Success," Harvard Business Review, 68/2 (March/April 1990): 130-140.

3. Igor Ansoff, Corporate Strategy (New York, NY: McGraw-Hill. 1965)

4. Kenneth R. Andrews, The Concept of Corporate Strategy (Homewood, IL: Irwin, 1987).

5. Ibid., p. xi.

6. Michael Porter, Competitive Strategy (New York, NY: Free Press, 1980).

7. Joe S. Bain, 1956. Barriers to New Competition (Cambridge, MA: Harvard University Press, 1956).

8. Michael Porter, Competitive Advantage (New York, NY: Free Press, 1985).

9. It is perhaps inevitable that our account of strategy is selective, and omits certain areas of academic inquiry. Among the branches that we have excluded from this account are approaches such as game theoretic views of strategy (Shapiro), sociologically informed approaches to strategy (Baum and Dutton), and chaos-based views of strategy (Brown and Eisenhart). Carl Shapiro, "The Theory of Business Strategy," The RAND Journal of Economics, 20/1 (Spring 1989): 125-137; Joel A.C. Baum and J.E. Dutton, eds., Advances in Strategic Management: The Embeddedness of Strategy (Greenwich, CT: JAI Press, 1996); Shona L. Brown and Kathleen M. Eisenhardt, Competing on the Edge : Strategy as Structured Chaos (Cambridge, MA: Harvard University Press, 1998.

10. Anita M. McGahan and Michael E. Porter, "How Much Does Industry Matter, Really?" Strategic Management Journal, 18/6 (Summer Special Issue 1997): 15-30; Anita M. McGahan and Michael E. Porter, "What Do We Know About Variance in Accounting Profitability?" Management Science, $48 / 7$ (July 2002): 834-851.

11. Richard Rumelt, "Diversification Strategy and Profitability," Strategic Management Journal, 3/4 (October-December 1982): 359-369; Richard P. Rumelt, "How Much Does Industry Matter?" Strategic Management Journal, 12/3 (March 1991): 167-185.

12. Birger Wernerfelt, "A Resource-Based View of the Firm," Strategic Management Journal, 5/2 (April/June 1984): 171-180; Jay B. Barney, “Strategic Factor Markets: Expectations, Luck, and Business Strategy," Management Science, 32/10 (October 1986): 1231-1241; Jay B. Barney, "Firm Resources and Sustained Competitive Advantage," Journal of Management, 17/1 (March 1991): 99-120; Ingemar Dierickx and Karel Cool, "Asset Stock Accumulation and the Sustainability of Competitive Advantage," Management Science, 35/12 (December 1989): 1504-1511; Ingemar Dierickx and Karel Cool, "Asset Stock Accumulation and the Sustainability of Competitive Advantage: Reply," Management Science, 35/12 (December 1989): 1514-1514; Joseph Mahoney and J. Rajendran Pandian, "The Resource-Based View within the Conversation of Strategic Management," Strategic Management Journal, 13/5 (June 1992): 363-380; M.A. Peteraf, “The Cornerstones of Competitive Advantage: A Resource-Based View," Strategic Management Journal, 14/3 (March 1993): 179-191.

13. David Teece, "Profiting from Technological Innovation," Research Policy, $15 / 6$ (1986): 285-305.

14. Donald Stokes, Pasteur's Quadrant: Basic Science and Technological Innovation (Washington, D.C.: Brookings Institution Press, 1997).

15. Thomas Kuhn, The Structure of Scientific Revolutions (Chicago, IL: University of Chicago Press, 1962).

16. For open source development, see Eric Raymond, The Cathedral and the Bazaar (Beijing: O'Reilly, 1999); Bruce Perens, The Emerging Economic Paradigm of Open Source < http://perens. com/Articles/Economic.html>, February 16, 2005; Eric von Hippel, Democratizing Innovation (Cambridge, MA: MIT Press, 2005). For open innovation, see Henry Chesbrough, Open Innovation: the New Imperative for Creating and Profiting from Technology (Boston, MA: Harvard Business School Press, 2003). For the intellectual commons, see Lawrence Lessig, The Future of Ideas: The Fate of the Commons in a Connected World (New York, NY: Random House, 2001). For peer production, see Josh Lerner and Jean Tirole, "Some Simple Economics of Open Source," Journal of Industrial Economics, 50/2 (June 2002): 197-234; Yochai Benkler, "Coase's Penguin, or, Linux and the Nature of the Firm," Yale Law Journal, 112/3 (December 2002): 369. For collective invention, see R.C. Allen, "Collective Invention," Journal of Economic Behavior and Organization, 4/1 (March 1983): 1-24.

17. Benkler, op. cit. 
18. Paul M. Romer, "Increasing Returns and Long-Run Growth," Journal of Political Economy, 94/5 (October 1986): 1002-1037.

19. Brian Arthur, Increasing Returns and Path Dependence in the Economy (Ann Arbor, MI: The University of Michigan Press, 1994).

20. Patricia Sellers, "MySpace Cowboys," $<$ http://money.cnn.com/magazines/fortune/fortune_archive/2006/09/04/8384727/index. htm>, August 292006.

21. Sean Michael Kerner, "IDC: Linux Ecosystem Worth $\$ 40$ Billion by 2010," <http://www.internetnews.com/dev-news/article.php/3659961>, February 14, 2007.

22. Don Tapscott and Anthony D. William, Wikinomics: How Mass Collaboration Changes Everything (New York, NY: Portfolio, 2006).

23. W. Brian Arthur, "Increasing Returns and the New World of Business," Harvard Business Review, 74/4 (July/August 1996): 100-110; Paul M. Romer, "Endogenous Technological Change," Journal of Political Economy, 98/5 (October 1990): S71-S102.

24. von Hippel, op. cit.; Sonali Shah, "Motivation, Governance, and the Viability of Hybrid Forms in Open Source Software Development," Management Science, 52/7 (July 2006): 1000-1014.

25. Michelle Delio, "Linux: Fewer Bugs Than Rivals," <www.wired.com/software/coolapps/news/2004/12/66022>, December 14, 2004; Mark Brunelli, "Users Tackle Question of Linux vs. Windows on the Server," <http://searchenterpriselinux.techtarget.com/originalContent/0,289142,sid39_gcil 123175,00.html?topic=3007 80>, September 8, 2005.

26. IDC, "Server Market Accelerates as New Workloads and a Strong Refresh Cycle Drive Server Demand in the Enterprise," <www.idc.com/getdoc.jsp;jsessionid=CHZBXSXEQGMI2CQJAFDCFFAKBEAVAIWD?containerId=prUS20840807>, August 23, 2007.

27. Robert McMillan, "Analysis: The Business Case for Desktop Linux," <www.computerworld.com.au/index.php/id;1048043952;fp;16;fpid;0>, December 24, 2004.

28. James Moore, The Death of Competition (Boston, MA: Harvard Business School Press, 1993)

29. Ibid.

30. Carl Shapiro and Hal Varian, Information Rules: A Strategic Guide to the Network Economy (Boston, MA: Harvard Business School Press, 1998).

31. Annabelle Gawer and Michael Cusumano, Platform Leadership (Boston, MA: Harvard Business School Press, 2002); Marco Iansiti and Roy Levien, The Keystone Advantage (Boston, MA: Harvard Business School Press, 2004).

32. Ownership also makes these sites potential targets for legal actions by copyright owners who feel that the site is monetizing value without paying appropriate compensation for the copyrighted content hosted on the site, such as the recent Viacom suit against YouTube. That is a subject for another paper, however.

33. Jon Perr, Patrick Sullivan, and Melissa M. Appleyard, “Open for Business: Emerging Business Models for Open Source Software Companies," working paper, Lab2Market, Portland State University, 2006; Henry Chesbrough, Open Business Models: How to Thrive in the New Innovation Landscape (Boston, MA: Harvard Business School Press, 2006).

34. JBoss was acquired by Red Hat in 2006.

35. Shapiro and Varian, op. cit.

36. von Hippel, op. cit.

37. Shah, op. cit.

38. <http://counter.li.org/>.

39. <http://blogs.zdnet.com/ITFacts/?p=6932>.

40. Mike Rogoway, "Merger Marks Open-Source Milestone," The Oregonian, January 23, 2007, pp. C1-C2.

41. Neil McAllister, "Questioning the Linux Foundation's credentials: How noble are its motivations?" CNET News, February 12, 2007.

42. Jared Diamond, Collapse: How Societies Choose to Fail or Succeed (New York, NY: Viking, 2005).

43. Linus Dahlander and Martin W. Wallin, "A Man on the Inside: Unlocking Communities as Complementary Assets," Research Policy, 35/8 (October 2006): 1243-1259.

44. von Hippel, op. cit.

45. Ibid.

46. Shah, op. cit.

47. Perr et al., op. cit. 
48. Gary Hamel, "Competition for Competence and Inter-Partner Learning within International Strategic Alliances," Strategic Management Journal, 12/4 (Summer 1991): 83-103.

49. Peter Grindley, David C. Mowery, and Brian Silverman, "SEMATECH and Collaborative Research: Lessons in the Design of High-Technology Consortia," Journal of Policy Analysis and Management, 13/4 (Autumn 1994): 723-758.

50. Chesbrough (2006), op. cit.

51. Morten Hansen, "The Search-Transfer Problem: The Role of Weak Ties in Sharing Knowledge across Organization Subunits," Administrative Science Quarterly, 44/1 (March 1999): 82.

52. Keld Laursen and Ammon Salter, "Open for Innovation: The Role of Openness in Explaining Innovation Performance among U.K. Manufacturing Firms," Strategic Management Journal, 27/2 (February 2006): 131-150.

53. Robert P. Merges, "A New Dynamism in the Public Domain," University of Chicago Law Review, 71 (2004): 183-203; Gary Pisano, Science Business: The Promise, the Reality, and the Future of Biotech (Boston, MA: Harvard Business School Press, 2006).

54. Cawley's quote is taken from Chesbrough (2006), op. cit., pp. 193-194. 